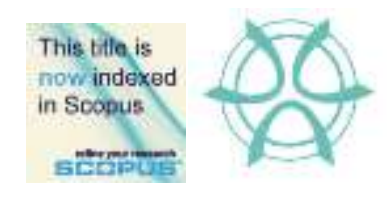

PLANNING MALAYSIA:

Journal of the Malaysian Institute of Planners

VOLUME 18 ISSUE 4 (2020), Page 365 - 374

\title{
CRITICAL REVIEW ON SUBURBAN TRANSIT ORIENTATION DEVELOPMENT
}

\author{
Mohamad Sabri Ahmad ${ }^{1}$, Robiah Suratman ${ }^{2}$ \\ ${ }^{1,2}$ Faculty of Built Environment and Surveying \\ UNIVERSITI TEKNOLOGI MALAYSIA
}

\begin{abstract}
Transit orientation development always been associated as the transport solution for traffic congestion especially in the city. Nevertheless, there is a gap in the research in the suburban area. This paper discusses about the possibility to apply the concept in the suburban area as the solution for urban sprawling. Therefore, four principles have been identified in order for a transit orientation development suit in the suburban necessity. The principles are being central area, density and mixed land uses; the connection between the central area and the transit; developed based on need of density and designed by specific development agency; funding mechanism to allow transit orientation development. The conclusion is transit orientation development is not applied for problem solving, but to avoid future issues.
\end{abstract}

Keywords: Transit Orientation Development, Suburban, Urban Sprawl

\footnotetext{
${ }^{1}$ Land Administration and Development Postgraduate Student Email: sabrijpbd@gmail.com
} 
Mohamad Sabri Ahmad, Robiah Suratman

Critical Review on Suburban Transit Orientation Development

\section{INTRODUCTION}

Development in suburban is the aftereffect of urban sprawling which emphasize the need for new space for housing. Furthermore, demand for private vehicle, increasing when the urban area expanding. As a result, house and work commuting for an hour become a norm every day because of the congestion and distance. Since 1980, Peter Calthorpe has started the idea of the transit orientation development to reduce pollution in high density development (Calthorpe, 1993). The core idea of the concept is to have a mix development within 400 meters until 800 meters diameter (Cervero, 2019). The combination of housing, commercial and public transport, especially railway within the radius promotes public transport usage and reduce car ownership because the train is easier to move around the city.

In that respect are various interpretations of transit orientation development that explain the concept and its effects. Firstly, transit orientation development required a mixed land use development within 600 meters walking distance of radius (Calthorpe, 1993). Next, the concept focuses on a transit station as to bring public transport location to be near to the user and increase the function of train (Brinckerhoff et al., 2002). Transit orientation development also offers high value on medium density housing because job opportunity and commercial activities nearby (Wilson, 2005). Another view is people will less dependent on cars because changing mode of transportation to the pedestrian, cycling, public transport, carpool and taxi. (Yap \& Goh, 2017). Furthermore, the concept encourages housing in the city centre and reduce road users (Rosni et al., 2018). Last but not least, the transit orientation development is concentrating on strategic accessibility and integration of transit station, which will support the mix land use and varying density to be living conducive (Cervero, 2019). However, the concept mostly applied to cities and not the suburban area where it has less density.

This paper wants to discuss on the preparation and suitability of suburban in implementing transit orientation development before it develops and merging with the city centre. Previous researches concentrate on Brazil, especially Curitiba city where transit orientation development concept being implemented using Bus Rapid Transit development (Cervero, 1998; Cervero \& Dai, 2014; Macke et al., 2018; Mercier et al., 2016; Miranda \& Silva, 2012; Smith \& Raemaekers, 1998). Unfortunately, the suburban preparedness for transit orientation development for future planning is never mentioned as the concept seems to be the problem solver for the car congestion issue.

\section{URBAN SPRAWL CREATES SUBURBAN}

Suburban emerged when the surrounding of the city boundary becomes more attractive for development, especially housing due to the affordable price and size of land. Urban sprawl started with rural area been converted into urban area 
because it is low density and the need for new spaces for city (Cervero \& Day, 2008; Rosni et al., 2018). Higher income has created housing in suburban in high demand because of the transport infrastructure network also expanding (Arrington \& Cervero, 2008; Duncan, 2011; Moos et al., 2015; Rosni et al., 2018). In addition, less density creates more transport distance movement comparable to the high density development (Rosni et al., 2018). Therefore, urban sprawl creates suburban due to the demand and resource availability; transportation mode also influenced by the distance of the commuting from the home to the city centre.

Accordingly, transportation is very important for the economy development that offer better transaction between two different geographical areas (Deng et al., 2016; Moos \& Mendez, 2015; Small, 2013). Still, people who live in the suburban has better quality of life and promote the low density and wide city development (Iseki \& Eom, 2019; Papa \& Bertolini, 2015; Rosni et al., 2018). This situation creates increasement of the private vehicle as the demand of quick and freedom mobility for people to less prefer the local bus services.

Furthermore, Cervero (2018) stated that density, variety and design of the city affect the accessibility directly. A well-design city is a pedestrian friendly that reduce the private transport on the road. Additionally, income and vehicle ownership are influencing the trip modes (B. Appleyard, 2012). Urban sprawl with the motorised vehicle is hard and nearly unstoppable. Consequently, suburban will have to confront issues such as lack of services in term of quality and quantity for public transport, private transport dominates roads, reduce access to job and necessity in the city.

\section{PRINCIPLES OF TRANSIT ORIENTATION DEVELOPMENT}

There are four principles of transit orientation development for city planning purposes such as central area and type of density with mixed land uses, quick connection between the centre and transit, development design for transits and lastly will be the support mechanism for funding the transit development as stated in Figure 1. These principles will be the guide to the concept of transit orientation development core to be applied to the suburban area. 
Mohamad Sabri Ahmad, Robiah Suratman

Critical Review on Suburban Transit Orientation Development

\section{Principle 1}

- central area, density and mixed land uses

\section{Principle 2}

- Connection between central area and the transit

Principle 3

- Development based on need of density and designed by specific development agency

\section{Principle 4}

- Funding mechanism to allow transit orientation development

Figure 1: Concept of Transit Orientation Development Principles Source: Cervero (2018); Cervero \& Sullivan (2011)

Principle one has two strategies starting with strategy one focus on the services and amenities within the scale suitable for density and economy. Services are preferable in high density to increase the efficiency and practicality (Pan et al., 2017; Singh et al., 2014). However, private vehicle becomes essential for people to get access to the services even with long range and causes central activity reduce the priority (Cervero \& Sullivan, 2011; Jones \& Ley, 2016; Singh et al., 2014). Significantly, the ability to understand the minimum of the radius for the central development as to ensure that people will use the public transport and services nearby rather than driving.

Next, strategy two is central area able to reduce private vehicle and retain the charm of suburban area. Expansion of the city can be avoid if the central development become the focus and well planned (Arrington, 2009; Cervero \& Sullivan, 2011; Kamruzzaman et al., 2014). Hence, new central area can be used as secondary tier of the services that connect suburban with the main central city. After that, the second principle has three strategies. Firstly, the private vehicle ownership is not encouraging due to the expanse on the commuting and vehicle rather than investing in cheaper public transport. Low income people prefer to own a vehicle because of the impression to reduce high cost rental in the city (Cervero, 2018; Dittmar \& Ohland, 2012). However, the hidden cost of maintenance, toll and fuel consumption increase their transportation cost to 40 percent of their income (Storeygard, 2016). Nevertheless, there should be an 
awareness campaign or a policy to reduce private vehicle and at the same time increase the quality of public transport.

The following strategy is people want to travel less than one hour (Arrington \& Cervero, 2008; Marchetti, 1994) and reluctantly to change mode of transport if the travel time is longer. As a result, considerable travel time through pedestrian or cycling mode is useful in order to attract people to change their behaviour that relying on private vehicle. The final criteria for principle two is the importance of the train. Train become the preferable choice because bus movement will be hindrance in the same congestion with the private vehicles (Cervero, 2016; Chorus, 2009). The train has the capability to move through anywhere in the city regarding the road congestions. Furthermore, the train uses less space and this is one of the reason city develop a light train system for traffic movement (Credit, 2018; Pan et al., 2017; Wang et al., 2019). Hence, train capability to easily move around the city become essential in the transit orientation development, especially in the suburbs that far away from the city centre.

Next, the principle three has two strategies and the lead by coordination and teamwork between local, states and federal authorities in order to implement the concept (Appleyard et al., 2019; Wang et al., 2019). Accordingly, statutory is the main mechanism to increase house ownership capability as the balancing the need for low income people and profit from commercialization in the development (Arrington \& Cervero, 2008; Moos et al., 2015; Rosni et al., 2018). Thus, the authorities able to implement the transit orientation development better with less interference from the political influence. The next strategy is to have cooperation between private and government sectors for transit orientation development in the city. The strategy emphasizes the development planning that benefits two parties which is the private sector for value property increment and government sector to utilize the profit for public facilities prioritize the train services (Cervero, 2019; Dittmar \& Ohland, 2012). The win-win situation could be an important key to develop the city based on transit orientation development.

In the end, the last principle has two strategies. The first strategy is to concentrate on one of the transportation funding mechanism. There are two systems, centrist road planning and market road planning. Centrist road planning is fully funded by the government (Storeygard, 2016) to develop road system in the country where market road planning based on the demand and income through tolls (Tolley \& Turton, 2014). While the second strategy is to convert the whole transportation system into train services (Cervero, 2016; Credit, 2018; Wang et al., 2019). Both strategies seem to be exclusively applicable in the idealistic world where the politician has no power in the financial decision to invest in the public transport and ignoring private vehicle ownership. 
Mohamad Sabri Ahmad, Robiah Suratman

Critical Review on Suburban Transit Orientation Development

\section{SUBURBAN TRANSIT ORIENTATION DEVELOPMENT ELEMENTS}

Therefore, based on the literature reviews, the propose of the transit orientation development in the suburban must has four elements which are population density, transit system, economic development and land use potential. Table 1 summarized the elements requirement that suitable for suburban transit orientation development. The first element is the population density where transit orientation development will be implemented on medium to high density development. This density capability to stimulate the local economy (Kamruzzaman et al., 2014). High density, good pedestrian network will offer a variety of transport modes, less car parks, high quality of city design which use less area than urban sprawl (Renne, 2016). In addition, transit orientation development not only create greater access for the people, but also reduce environment maintenance (Dittmar \& Ohland, 2012). As a result, small area with medium to high density development will be the main activity to reduce the rural area consumption.

Table 1: Suburban Transit Orientation Development Elements

\begin{tabular}{|c|c|c|c|}
\hline Elements & Indicator & Measurement & Reference \\
\hline \multirow{3}{*}{$\begin{array}{l}\text { Population } \\
\text { Density }\end{array}$} & People Density & Population/ sq km & Wang et al., 2019 \\
\hline & $\begin{array}{l}\text { Commercial } \\
\text { Density }\end{array}$ & $\begin{array}{l}\text { Commercial activity/ sq } \\
\mathrm{km}\end{array}$ & Wang et al., 2019 \\
\hline & Jobs Level & Jobs total/ sq km & Wang et al., 2019 \\
\hline \multirow{7}{*}{$\begin{array}{l}\text { Transit } \\
\text { System }\end{array}$} & $\begin{array}{l}\text { Passenger during } \\
\text { peak hour }\end{array}$ & $\begin{array}{c}\text { Total passenger/ transport } \\
\text { capacity }\end{array}$ & Pan et al., 2017 \\
\hline & $\begin{array}{l}\text { Passenger during } \\
\text { outside peak hour }\end{array}$ & $\begin{array}{c}\text { Total passenger/ transport } \\
\text { capacity }\end{array}$ & Pan et al., 2017 \\
\hline & Safety & $\begin{array}{l}\text { Safety during waiting and } \\
\text { in the vehicle }\end{array}$ & Appleyard, 2012 \\
\hline & Facilities & $\begin{array}{l}\text { Shelter, waiting room, } \\
\text { seats, shops, restaurant } \\
\text { and lighting }\end{array}$ & Appleyard, 2012 \\
\hline & Information Panel & $\begin{array}{l}\text { Plan and design of the } \\
\text { station, disable people } \\
\text { access, signage }\end{array}$ & Chow et al., 2014 \\
\hline & $\begin{array}{c}\text { Service } \\
\text { Frequency }\end{array}$ & $\begin{array}{l}\text { High frequency equal } \\
\text { high accessibility }\end{array}$ & $\begin{array}{l}\text { Appleyard et al., } \\
2019\end{array}$ \\
\hline & $\begin{array}{c}\text { Connection } \\
\text { between another } \\
\text { route }\end{array}$ & $\begin{array}{c}\text { Connection between } \\
\text { routes }\end{array}$ & Iseki \& Eom, 2019 \\
\hline
\end{tabular}


PLANNING MALAYSIA

Journal of the Malaysia Institute of Planners (2020)

\begin{tabular}{|c|c|c|c|}
\hline & $\begin{array}{l}\text { Interchange with } \\
\text { another mode }\end{array}$ & Modes connectivity & Iseki \& Eom, 2019 \\
\hline & Station access & $\begin{array}{l}\text { Spatial readiness and total } \\
\text { population that can afford } \\
\text { the transit node }\end{array}$ & $\begin{array}{l}\text { Cervero \& Day, } \\
2008\end{array}$ \\
\hline & Parking & User and space ratio & Renne, 2007 \\
\hline \multirow{2}{*}{$\begin{array}{c}\text { Economy } \\
\text { Development }\end{array}$} & $\begin{array}{c}\text { Private } \\
\text { investment in } \\
\text { local authority }\end{array}$ & Total investment & $\begin{array}{l}\text { Cervero \& Dai, } \\
2014\end{array}$ \\
\hline & $\begin{array}{l}\text { Total existing } \\
\text { commercial }\end{array}$ & Total business/ sq km & $\begin{array}{c}\text { Cervero \& Day, } \\
2008\end{array}$ \\
\hline \multirow{2}{*}{$\begin{array}{l}\text { Land } \\
\text { Development } \\
\text { Potential }\end{array}$} & Mixed land use & $\begin{array}{l}\text { Dissimilarity index, } \\
\text { activity centre mixture, } \\
\text { commercial intensities }\end{array}$ & Cervero, 2018 \\
\hline & $\begin{array}{l}\text { Level of mixed } \\
\text { land use }\end{array}$ & $\begin{array}{l}\text { Mixed land use of } \\
\text { housing and others }\end{array}$ & Cervero, 2019 \\
\hline
\end{tabular}

The second component is the transit system that emphasises on the planning the transit system development that able to attract people to utilise it. Lack of planning will lead to the public transportation as the bottom of people's choices which will be a waste of investments (Rosni et al., 2018). A perfect location of transit station, especially in the high density area will be very helpful for people movement with high frequency services (Kamruzzaman et al., 2014; Renne, 2016). Thus, a well-planned of transit system will pull masses to abandon private vehicle and reduce the car dependency.

The next element is the economic development that concentrates on the capability to enhance the local economy in the centre of the transit of development. The mixed land use promotes commercial activity where the supply and the demand stay close to each other. This commercial area also will become the focal point of the area and offer jobs or entrepreneurship opportunity for the residents nearby (Renne, 2009). The short distance between infrastructures will lead to the economic development and as a result, local income also increase (Renne, 2009; Wang et al., 2019). Therefore, without a doubt there is higher possibility that suburban can increase their economy by implementing transit orientation development. Land development potential become the last element in the suburban transit orientation development. This last element focus on the capability of the transit nodes to increase the public transport usage, support local business and create a high quality of life neighbourhood (Dittmar \& Ohland, 2012; Renne, 2009). Consequently, the land will be use very efficient and become, the more reliable solution compares to urban sprawling. 
Mohamad Sabri Ahmad, Robiah Suratman

Critical Review on Suburban Transit Orientation Development

\section{CONCLUSION}

As the conclusion, transit orientation development is suitable for the suburban especially during the city expands. The land can be maximised utilised to the highest potential with less problematic in the future. Furthermore, this concept not only become the congestion solution but also to be the new type of the city that has good quality of life. So far, the concept has been applied to solve the congestion problems, but there is a potential for planner and researcher to explore or create a transit orientation development starting from the suburbs.

\section{ACKNOWLEDGEMENTS}

The authors would like to acknowledge the support from Universiti Teknologi Malaysia (UTM). The authors also grateful and thankful to all the reviewers for their contributions in improving this article.

\section{REFERENCES}

Appleyard, B. (2012). Sustainable and Healthy Travel Choices and the Built Environment: Analyses of Green and Active Access to Rail Transit Stations along Individual Corridors. Transportation Research Record, 2303(1), 38-45.

Appleyard, B. S., Rost, A. R., \& Allen, C. (2019). Are All Transit Stations Equal and Equitable? Calculating Sustainability, Livability, Health, \& Equity Performance of Smart Growth \& Transit-Oriented-Development (TOD). Journal of Transport \& Health, 14 .

Arrington, G. B. (2009). Portland's TOD Evolution: from Planning to Lifestyle. In C. Curtis, J. L. Renne, \& L. Bertolini (Eds.), Transit Oriented Development: Making it Happen (pp. 109-124). Ashgate.

Arrington, G. B., \& Cervero, R. (2008). TCRP Report 128: Effects of TOD on Housing, Parking, and Travel.

Brinckerhoff, P., Boroski, J., Faulkner, T., \& Arrington, G. B. (2002). Parking and TOD: Challenges and Opportunities.

Calthorpe, P. (1993). The Next American Metropolis: Ecology, Community, and the American Dream. Princeton Architectural Press.

Cervero, R. (1998). The Transit Metropolis: A Global Inquiry. Island Press.

Cervero, R. (2016). Transit-Oriented Development and the Urban Fabric. Routledge.

Cervero, R. (2018). America's Suburban Centers: The Land Use-Transportation Link (Vol. 6). Routledge.

Cervero, R. (2019). The Transit Metropolis: A 21st Century Perspective. In E. Deakin (Ed.), Transportation, Land Use, and Environmental Planning (pp. 131-149). Elsevier.

Cervero, R., \& Dai, D. (2014). Leveraging Transit Oriented Development with Bus Rapid Transit Investments. Transport Policy, 36, 127-138.

Cervero, R., \& Day, J. (2008). Suburbanization and Transit-Oriented Development in China. Transport Policy, 15(5), 315-323.

Cervero, R., \& Sullivan, C. (2011). Green TODs: Marrying Transit-Oriented Development and Green Urbanism. International Journal of Sustainable 
Development \& World Ecology, 18(3), 210-218.

Chorus, P. (2009). Transit- Oriented Development in Tokyo: the Public Sector Shapes Favourable Conditions, The Private Sector Makes it Happen. In C. Curtis, J. L. Renne, \& L. Bertolini (Eds.), Transit Oriented Development: Making it Happen (pp. 209-224). Ashgate.

Chow, W., Block-Schacter, D., \& Hiskey, S. (2014). Impacts of Real-Time Passenger Information Signs in Rail Stations at the Massachusetts Bay Transportation Authority. Transportation Research Record, 2419(1), 1-10.

Credit, K. (2018). Transit-Oriented Economic Development: The impact of Light Rail on New Business Starts in the Phoenix, AZ Region, USA. Urban Studies, 55(13), 2838-2862.

Deng, T., Ma, M., \& Nelson, J. D. (2016). Measuring the Impacts of Bus Rapid Transit on Residential Property Values: The Beijing Case. Research in Transportation Economics, 60(December 2016), 54-61.

Dittmar, H., \& Ohland, G. (2012). The New Transit Town: Best Practices In TransitOriented Development. Island Press.

Duncan, M. (2011). The Impact of Transit-Oriented Development on Housing Prices in San Diego, CA. Urban Studies, 48(1), 101-127.

Iseki, H., \& Eom, H. (2019). Impacts of Rail Transit Accessibility on Firm Spatial Distribution: Case Study in the Metropolitan Area of Washington, DC. Transportation Research Record, 2673(11), 220-232.

Jones, C. E., \& Ley, D. (2016). Transit-Oriented Development and Gentrification along Metro Vancouver's Low-Income SkyTrain Corridor. The Canadian Geographer, 60(1), 9-22.

Kamruzzaman, M., Baker, D., Washington, S., \& Turrell, G. (2014). Advance Transit Oriented Development Typology: Case Study in Brisbane, Australia. Journal of Transport Geography, 34, 54-70.

Macke, J., Casagrande, R. M., Sarate, J. A. R., \& Silva, K. A. (2018). Smart City and Quality of Life: Citizens' Perception in a Brazilian Case Study. Journal of Cleaner Production, 182, 717-726.

Marchetti, C. (1994). Anthropological Invariants in Travel Behavior. Technological Forecasting and Social Change, 47(1), 75-88.

Mercier, J., Carrier, M., Duarte, F., \& Trembley-Racicot, F. (2016). Policy Tools for Sustainable Transport in Three Cities of the Americas: Seattle, Montreal and Curitiba. Transport Policy, 50, 95-105.

Miranda, H. D. F., \& Silva, A. N. R. D. (2012). Benchmarking Sustainable Urban Mobility: The Case of Curitiba, Brazil. Transport Policy, 21, 141-151.

Moos, M., Kramer, A., Williamson, M., Mendez, P., McGuire, L., Wyly, E., \& WalterJoseph, R. (2015). More Continuity than Change? Re-Evaluating the Contemporary Socio-Economic and Housing Characteristics of Suburbs. Canadian Journal of Urban Research, 24(2), 64-90.

Moos, M., \& Mendez, P. (2015). Suburban Ways of Living and the Geography of Income: How Homeownership, Single-Family Dwellings and Automobile Use Define the Metropolitan Social Space. Urban Studies, 52(10), 1864-1882.

Pan, H., Li, J., Shen, Q., \& Shi, C. (2017). What Determines Rail Transit Passenger Volume? Implications for Transit Oriented Development Planning. 
Mohamad Sabri Ahmad, Robiah Suratman

Critical Review on Suburban Transit Orientation Development

Transportation Research Part D: Transport and Environment, 47, 52-63.

Papa, E., \& Bertolini, L. (2015). Accessibility and Transit-Oriented Development in European Metropolitan Areas. Journal of Transport Geography, 47, 70-83.

Renne, J. L. (2007). Urban Sustainability Through Environmental Design: Approaches to Time-People-Place Responsive Urban Spaces.

Renne, J. L. (2009). From Transit-Adjacent to Transit-Oriented Development. Local Environment, 14(1), 1-15.

Renne, J. L. (2016). Transit Oriented Development: Making It Happen. Routledge.

Rosni, N. A., Ponrahono, Z., \& Noor, N. M. (2018). Segregated land Use Sprawl: TOD Approach for Mix Used Housing Development in Kuala Lumpur. Planning Malaysia Journal, 16(5).

Singh, Y. J., Fard, P., Zuidgeest, M., Brussel, M., \& VanMaarseveen, M. (2014). Measuring Transit Oriented Development: A Spatial Multi Criteria Assessment Approach for the City Region Arnhem and Nijmegen. Journal of Transport Geography, 35, 130-143.

Small, K. (2013). Urban Transportation Economics (Vol. 4). Taylor \& Francis.

Smith, H., \& Raemaekers, J. (1998). Land Use Pattern and Transport in Curitiba. Land Use Policy, 15(3), 233-251.

Storeygard, A. (2016). Farther on Down the Road: Transport Costs, Trade and Urban Growth in Sub-Saharan Africa. The Review of Economic Studies, 83(3), 12631295 .

Tolley, R., \& Turton, B. J. (2014). Transport Systems, Policy and Planning: A Geographical Approach.

Wang, X., Tong, D., Gao, J., \& Chen, Y. (2019). The Reshaping of Land Development Density through Rail Transit: The Stories of Central Areas vs. Suburbs in Shenzhen, China. Cities, 89, 35-45.

Wilson, R. (2005). Parking Policy for Transit-Oriented Development: Lessons for Cities, Transit Agencies, and Developers. Journal of Public Transportation, 8(5), 5.

Yap, J. B. H., \& Goh, S. V. (2017). Determining the Potential and Requirements of Transit-Oriented Development (TOD) The Case of Malaysia. Property Management, 35(4), 394-413.

Received: $15^{\text {th }}$ May 2020. Accepted: $1^{\text {st }}$ Sept 2020 